To give proper effect to the rule, the Board would have to be on guard against a premature finding that the strike is ended by placing an unwarranted reliance on precedents based on this or other statutes covering termination of a strike for other purposes. Under the proposed rule necessary administrative delay does not operate to confuse the collective bargaining obligation, since this obligation remains unchanged until the decision is announced. The operation of the Wurlitzer and Taft-Hartley rules creates an interim period of confusion during which the employer's obligation to bargain is suspended for want of an ascertained party with whom to deal.

\title{
PROTECTION FROM DEFAMATION IN CONGRESSIONAL HEARINGS
}

One of the aims of the House Committee on Un-American Activities ${ }^{x}$ has been to "permit the greatest court in the world-the court of American public opinion-to have an undirected, uncensored, and unprejudiced opportunity to render a continuing verdict on all of its public officials and to evaluate the merit of many in public life...." The marked skill and success of the Committee in pursuing this course have lead to widespread controversy. ${ }^{3}$ Regardless of the

but other factors are the extent of resumption of normal operations, the loss of business, and the tort notion of whether there remains someone to benefit from the activity or whether its object has "become no more than an effort to injure the employer"); The Determination of When a Strike Is Ended, $38 \mathrm{Col}$. L. Rev. 676 (9938), noting Mode Novelty Co. v. Taylor, r22 N.J. Eq. 593, x95 Atl. 8r9 (1937) ("A strike is terminated when the places of strikers have been filled with competent men, and the employer's business is operating in a normal manner and to a normal extent"); cf. Rest., Torts $\$ 776$, comment b. (r939).

I Originally created as a special committee by H. Res. 282, 75th Cong. 3 d Sess. (I938), the Un-American Activities Committee was continued by successive resolutions until I945. H. Res. 26, 76th Cong. Ist Sess. (I939); H. Res. 321, 76th Cong. 3d Sess. (x940); H. Res. 9o,

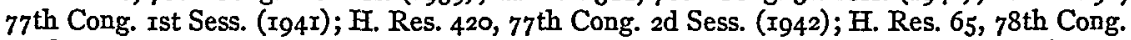
Ist Sess. (I943). It was made a standing committee by H. Res. 5, 79th Cong. Ist Sess. (1945), and has since been authorized by the Legislative Reorganization Act of $1946 \S \mathrm{r} 2 \mathrm{I}(\mathrm{b})(\mathrm{x})(\mathrm{q})$, 60 Stat. 828 (I946). The purposes of the Committee were defined in these enactments as follows: "The Committee on Un-American Activities, as a whole or by subcommittee, is authorized to make from time to time investigations of (i) the extent, character, and objects of unAmerican propaganda activities in the United States, (ii) the diffusion within the United States of subversive and un-American propaganda that is instigated from foreign countries or of a domestic origin and attacks the principle of the form of government as guaranteed by our Constitution, and (iii) all other questions in relation thereto that would aid Congress in any necessary remedial legislation."

${ }^{2}$ Interim Report of the House Committee on Un-American Activities on the Hearings regarding Communist Espionage in the United States Government, 8oth Cong. 2d Sess., at r-2 (1948).

3 The professed aims of the Committee, its sincerity in espousing them, and the procedures adopted have all been criticized. The leading work on procedure is Ogden, The Dies Committee (2d ed., I945), while differing viewpoints as to the Committee's worth are presented by Zahn, Hollywood on Trial (I948); Cohn, Those Investigating Committees, reproduced in Thought Control in U.S.A. 40 (I947); Letter from the members of the Yale Law School faculty to the President of the United States, the Secretary of State, and the Speaker of the House of Representatives, reprinted in "Lawyer Schools" or "Policy Science"? Yale Law School's Manifesto Stirs Debate, 34 A.B.A.J. I5, I6 (r948); Gelhorn, Report on a Report of the House Committee 
value attributed to the Committee's latest discoveries, the need for protection of individual privacy and reputation has been dramatized by recent events beginning with the Committee's hearings at which Elizabeth T. Bentley and Whittaker Chambers made their sensational charges concerning Communist espionage in the government, ${ }^{4}$ and culminating with publication and retraction of accusations against Laurence Duggan. ${ }^{5}$

Whereas discussion and litigation have heretofore centered largely on attempts to protect the recalcitrant witness from committee efforts to compel testimony and the production of documents, ${ }^{6}$ these episodes indicate that protection of third parties against possible defamation by friendly witnesses or Committee members currently constitutes a more pressing problem. Reconsideration of alternative safeguards against unwarranted damage to reputation is appropriate in view of the possibilities of legislative action suggested by President Truman's publicized hostility to the Committee. ${ }^{7}$ And, because the Committee's practices have so frequently changed, ${ }^{8}$ suggested reforms may best be appraised in the light of the "Hearings regarding Communist Espionage in the United States Government,"9 the latest chapter in the Committee's history.

Although many constitutional doubts have been raised as to the Committee, it appears unlikely that direct constitutional attack will be successful. ${ }^{x 0}$ And in

on Un-American Activities, 6o Harv. L. Rev. Ir93 (1947); Liebling, The Whole Story, 24 New Yorker, No. 38, at 134 (Nov. I3, I948); Straight, Trial by Congress, II9 New Republic, No. 7, at 6 (Aug. I6, I948); Mundt, What Is Un-American Activity? Liberty I9 (Sept. 22, 1945); What Is Americanism? N.Y. Times, $\$ 4$, p. 6, col. I (Dec. 26, I948).

4 N.Y. Times, § I, p. I, col. 4 (Aug. I, I948); N.Y. Times, § I, p. I, col. I (Aug. 4, I948).

$s$ Chi. Daily Tribune, p. I, col. 2 (Dec. 2I, I948); Chi. Daily Tribune, p. I, col. I (Dec. 22, I948).

${ }^{6}$ See note Io infra.

7 The hearings have been characterized by President Truman as a "red herring." Chi. Daily News, p. r, col. 7 (Dec. 9, I948).

8 See Ogden, The Dies Committee (2d ed., I945).

9 Hearings before the House Committee on Un-American Activities regarding Communist Espionage in the United States Government, 8oth Cong. 2d Sess. (I948).

10 It has been primarily the desire to afford privacy to the individual which has lead to the attempts to impose constitutional restraints on the Committee's actions. Some of the arguments have been addressed at the constitutionality of the investigations undertaken. Thus, it has been claimed that the Committee's inquiries abridged free speech and inflicted punishment without trial, while absence of any legislative purpose has also been urged as a defect. It has been said that the investigation "as now authorized would necessarily have as its subject the 'private affairs of private citizens,' " and furthermore, that politically discriminatory administration of the resolution authorizing the Committee has resulted in a denial of "equal protection." Finally, the contention has been raised that lack of an ascertainable standard of guilt renders unconstitutional any conviction for contempt, a supposed result of the ambiguity of the resolution defining the scope of inquiry. However, the constitutionality of the Committee has been twice upheld in lower federal court opinions which the Supreme Court has refused to review. Barsky v. United States, I67 F. 2d 24I (App. D.C., I948), cert. den. 68 S. Ct. I5II (I948); United States v. Josephson, I65 F. 2d 82 (C.C.A. 2d, I947), cert. den. 333 U.S. 838 (I948), rehearing den. 333 U.S. $85^{8}$ (I948). Other suggested constitutional limitations spring 
any event, unless it succeeds in eliminating the Committee altogether, it will not afford significant protection against defamation. ${ }^{\mathrm{II}} \mathrm{A}$ more responsible press ${ }^{\mathrm{I2}}$ and improvement in the caliber of Committee personnel ${ }^{13}$ would of course reduce the need for extensive reform, but these offer little hope of early or permanent realization. Increased power to control the effects of defamatory testimony must be lodged in either the party defamed or the courts. Reform proposals to be examined in this note are then of two types: legislative reform of the Committee's procedure designed to equalize the positions of the accuser and accused in the forum provided by the Committee itself, and the imposition of criminal or civil sanctions on the person responsible for defamation.

\section{I}

Of the numerous proposals for legislative reform of congressional committees embodied in bills introduced in Congress, ${ }^{{ }^{x 4}}$ the reports of bar associations, ${ }^{, 5}$ and

from rights available to witnesses in any investigation. Protection may be afforded by the requirement that the question asked be pertinent to the inquiry and through safeguards provided by the searches and seizures clause and the privilege against self-incrimination. For discussion of constitutional law issues raised with regard to either type of limitation see Validity of the Un-American Activities Committee Inquiries into Professional and Political Affiliations, 46 Mich. L. Rev. 52I (I948); Constitutional Limitations on the Un-American Activities Committee, 47 Col. L. Rev. 4 r6 (I947); Congressional Contempt Power in Investigations in to the Area of Civil Liberties, I4 Univ. Chi. L. Rev. 256 (r947). For detailed discussion of selfincrimination, see Applicability of Privilege against Self-incrimination to Legislative Investigations, 49 Col. L. Rev. 87 (I949).

Ix Even should the Committee be declared unconstitutional, Congress would still undoubtedly be able to conduct investigations as to the subject of espionage in the government. Any court pronouncement would probably limit only the power of a committee to compel testimony from recalcitrant witnesses. Thus opportunity might still exist for defamation by the friendly witness. It must also be remembered that the assertion of a purported constitutional privilege may seriously prejudice the witness in the eyes of the public. For example, refusal to testify on the ground of possible self-incrimination is often considered tantamount to a confession. See statement of Representative Rankin, Hearings before the House Committee on UnAmerican Activities regarding Communist Espionage in the United States Government, 8oth Cong. 2d Sess., at 594 (x948): "If you had committed no crime your testimony would not incriminate you. I have been a prosecuting attorney and I have never seen a man refuse to answer questions on the ground that they would incriminate him except when he had committed a crime himself." Cf. Adamson v. California, 332 U.S. 46 (I947).

${ }^{22}$ See Liebling, The Wayward Press, 24 New Yorker, No. 27, at 40 (Aug. 28, 1948); No. 28, at 54 (Sept. 4, r948); No. 35, at 78 (Oct. 23, r948).

${ }{ }_{3}$ The Democratic Committee on Committees has recently adopted resolutions barring chairmen of other committees and non-lawyers from serving on the Un-American Activities Committee and thereby removed Representatives Rankin and Hébert. N.Y. Times, $\S I$, p. I4, col. 6 (Jan. I8, I949). Two other Committee members, Representatives Vail and McDowell, were defeated in bids for re-election.

${ }_{4}$ Measures rejected by the last Congress included S. Con. Res. 44, 8oth Cong. 2d Sess. (1948), introduced by Senator Lucas of Illinois, and H.R. 464I, 8oth Cong. xst Sess. (I948), introduced by Rep. Holifeld of California. The major provisions of both, as well as a number of additional rules, are contained in H.R. 74, 81st Cong. rst Sess. (I949).

${ }^{x}$ New York City Bar Ass'n, Committee on the Bill of Rights, Report on Congressional Investigations (I948), recommended for legislative enactment requirements that the subject 
the writings and speeches of individuals, ${ }^{16}$ the most extensive in scope is the bill introduced in the Eighty-first Congress by Representative Holifield of California. ${ }^{17}$ The Holifield Bill which incorporates virtually all of the major proposals for reform would secure to any person who believed that his reputation had been harmed by testimony given in a public hearing before any congressional committee the right to file with the committee a sworn statement to be made part of the record of the hearings and the right to testify personally in his own behalf. He would also be given the right to compel the committee to secure

of any investigation be announced before hearings were commenced and only relevant evidence be elicited, that accurate stenographic record be kept of all testimony, and that no photographs, moving pictures, television or radio broadcasting of the proceedings be permitted while a witness was testifying. Rights to be granted the witness included that of counsel, of making written or oral statements supplementing testimony, and of free access to the record of his testimony. The person harmed was to be afforded the privileges of filing sworn statements with the committee, appearing personally to testify in his own behalf, and of cross-examining adverse witnesses for a limited period of time. A further power to be granted him, the right to have the committee call witnesses in his behalf, was to be subject to the committee's discretion. Proced'ural principles for committee adoption were suggested in Recommendations for the Protection of Civil Rights in Legislative Investigations, $3 \circ$ Chi. Bar Rec. 7 I (I948). They included granting to the witness the right to counsel, and requirements that formal hearings be public and that secret, preliminary conferences be used to avoid unnecessary injury to reputation. It was suggested that persons harmed be given the right to file sworn statements and that no hearirgs be conducted without at least two committee members present. Witnesses would be given the right to cballenge subpoenas by motion before the committee. Testimony of witnesses would have to be of "substantial probative force" and, where reasonable, about facts within their knowledge. No inquiry would be made as to unexpressed beliefs of private individuals. Finally, committee reports would be limited by requirements that a report be essential to $t$ he legislative purpose of the investigation, that a majority of the committee consent to its issuance, and that it be based only on evidence presented at public hearings.

${ }^{x} 6$ Moderate curbs were proposed by Judge Wyzanski in a recent magazine article, Defects of Congressional Investigations, 38 Fortune, No. 5, at I80 (Nov. I948). The author thought that a statute setting out the "minimum standards for a legislative inquiry" would include "the right of the witness to have counsel present, to file a written statement before the hearing concluded, to have an accurate record kept of his own testimony, and to have public reports of the committee based only on public evidence." Other reforms worthy of "professional consideration" but not practical at present: a private person would not be compelled to testify in camera unless the majority of the committee explicitly ruled that the publicinterest required that the testimony be kept secret; a witness would not be compelled to testify unless more than one committee member was present; a person criticized would be allowed to file with the committee "a limited number of written interrogatories" which would have to be answered in writing by the hostile witness, unless the majority of the committee directed otherwise; and no private persons would be compelled to testify unless the majority of the committee approved the issuance of a subpoena. That not all members of the Thomas Committee were themselves insensitive to criticisms of its procedure is indicated by Rep. Nixon's remarks before the New York Herald Tribune Forum. He there suggested a pattern for congressional committee investigations under which individual rights would be protected. Any individual named as a possible loyalty risk would have an equal opportunity to present his side of the case in the same forum where accused; he would have the right to counsel at all times, the right to present witnesses in his own behalf, and to make statements pertinent to the issues involved; and furthermore, no report involving an individual's loyalty would be issued by the committee until hearings had been held and the individual had had an opportunity to appear. N.Y. Herald Tribune, \& Io, p. 53, col. 5 (Oct. 24, r948).

${ }_{77}$ H.R. 74, 8Ist Cong. Ist Sess. (I949). 
the appearance of a limited number of witnesses requested by him whom he might examine either personally or by counsel. Witnesses whose testimony adversely affected him could be cross-examined for a limited length of time, again either personally or by counsel. No person would be compelled to testify or produce documents unless a majority of the committee approved the issuance of a subpoena; secret hearings could be held only upon an order of a majority of the committee, and then only in the event that two members were present in addition to the interrogator. All witnesses would be granted the right to counsel and to make relevant oral statements or to file sworn ones at the conclusion of their testimony. They would also be entitled to stenographic transcripts of their reported testimony, which would necessarily include all testimony given in public hearings. Any witness whose testimony was impeached would be permitted to question the impeaching witness by means of written interrogatories, though the extent of this privilege would be subject to committee discretion. Furthermore, the committee would have to advise witnesses of their constitutional rights to withhold information, and furnish an opportunity to present through counsel written motions and oral arguments when a privilege was claimed. A witness would be adjudged of contempt only upon a majority vote at a committee meeting called for that purpose. The bill further provides that the committee receive only evidence that is relevant to the subject of the hearings and that reports be filed or published only after approval at a committee meeting. Another provision would prevent committee members or employees from publishing statements adversely commenting on any person until he had been advised of his alleged misconduct and given a reasonable time to present a sworn statement. The release of such statements would be subject to approval at a meeting by a quorum of the whole committee. Finally, committee members and employees would be prohibited from speaking or writing for compensation about any phase of the committee's activities.

Because the proposed reforms would apply to all congressional committees, there has been considerable anxiety over the burdens which would thereby be placed on congressional investigations. It is generally agreed that such investigations are essential at least in obtaining the information necessary for lawmaking and in promoting responsible government by congressional supervision of the executive department. ${ }^{18}$ It is true that the obstructionist witness could manipulate these safeguards to delay and confuse the proceedings. ${ }^{19}$ It might be well to have a less rigorous set of rules for congressional investigations which

${ }^{18}$ For general discussion of this problem, see Ogden, The Dies Committee, c. I (2d ed., I945); McGeary, Developments of Congressional Investigative Power (r940); Dimock, Congressional Investigating Committees (1929); Eberling, Congressional Investigations (I928); Ehrmann, The Duty of Disclosure in Parliamentary Investigation: A Comparative Study, Ix Univ. Chi. L. Rev. I, II7 (x943-44); Landis, Constitutional Limitations on the Congressional Power of Investigation, 40 Harv. L. Rev. I53 (1926); Frankfurter, Hands off Congressional Inquiries, 38 New Republic 329 (I924).

${ }^{19}$ For an analysis of the difficulties which can occur in multiple party proceedings, see The Sedition Trial: A Study in Delay and Obstruction, I5 Univ. Chi. L. Rev. 69I (I948). 
do not involve "subversive" activity. But even though this may not be politically feasible, it does not seem probable that these proposed restrictions would seriously handicap effective investigation. Some check against deliberate procedural abuse would be provided by public opinion. Common-sense notions of justice and fair play argue for the adoption of these rules..$^{30}$ And if they are to be effective they should be codified by statute and thus placed beyond the reach of the whims of a particular committee..$^{2 x}$

But excessive optimism that statutory reform will eliminate possible defamation does not seem warranted when it is recognized that many of the proposed rules were observed during the Communist espionage hearings. Thus, witnesses were allowed to read prepared statements before the Committee, ${ }^{22}$ and the depositions and letters of persons unable to appear were printed in the record. ${ }^{23}$ Although not apprised of the charges beforehand, ${ }^{24}$ all persons accused during public hearings of participating in Communist espionage activities were given the opportunity to appear and testify in their behalf. ${ }^{25}$ The right to introduce favorable witnesse ${ }^{26}$ and to cross-examine opposing ones was denied, ${ }^{27}$ but when

${ }^{20}$ The rule requiring that committee members or employees obtain committee permission before commenting adversely about anybody is of doubtful desirability since it could easily lead to the gagging of minority members of committees. The need underlying the other rules is amply illustrated by the past record of the Un-American Activities Committee. See Ogden, The Dies Committee (2d ed., 1945); Kahn, Hollywood on Trial (x948); Gelhorn, Report on a Report of the House Committee on Un-American Activities, 60 Harv. L. Rev. II93 (I947). For a critique of the procedure used in the Kerr Committee's investigation of the loyalty of government employees see Cushman, The Purge of Federal Employees Accused of Disloyalty, 3 Pub. Admin. Rev. 297 (1943).

2x See Representative Thomas' statement regarding the present situation. Hearings before the House Committee on Un-American Activities regarding Communist Espionage in the United States Government, 8oth Cong. 2d Sess., at I3ro (r948). "The rights you have are the rights given you by this committee. We will determine what rights you have and what rights you have not got before the committee."

$$
\begin{aligned}
& { }_{22}^{2} \text { Ibid., at 589, 642, 699, 723, 767, 805, 84I, 852, 878, 907, 913, 916, } 928 . \\
& { }_{23} \text { Tbid., at r358-6r. } \quad 24 \text { Ibid., at } 657-58,878 \text {. }
\end{aligned}
$$

${ }_{25}$ See House Committee on Un-American Activities, op. cit. supra note 2, at 6; House Committee on Un-American Activities, op. cit. supra note 9, at 537. Representative Hébert's views expressed in the latter reference seemingly represented the position of the majority of the Committee. "If anybody puts in jeopardy an individual who is charged with being a Communist, I think, in fairness, that this individual should be allowed his day in court here in public hearing as well. Now if you were in secret session or executive session, and these names were used, then we owe them no obligation, but the minute that we allow a witness on the stand to mention any individual, that individual has a right to come before this committee and have his day in court. ..."

${ }^{36} \mathrm{~A}$ list of prospective witnesses submitted by Alger Hiss was disregarded by the Committee. Hearings before the House Committee on Un-American Activities regarding Communist Espionage in the United States Government, 8oth Cong. 2d Sess., at I162-65 (1948). These were in the nature of character witnesses, however, and the Committee's actions do not necessarily reflect on its expressions of willingness to examine witnesses for the purpose of corroborating the "facts." Ibid., at 987, rogo-92.

${ }^{27}$ Ibid., at 926 . The reason given for the Committee's actions by Representative Mundt is itself in need of explanation. "The position of this committee has been ... that we are not 
requested the Committee did ask the adverse witness questions submitted by the accused. ${ }^{28}$ It also appears that transcripts of testimony could be obtained by witnesses. ${ }^{29}$ Moreover, all of the witnesses were granted the right to counsel, though generally attorneys were not allowed to participate in the proceedings to the extent of personally interposing objections to questions. ${ }^{30}$ These safeguards did not prevent harm to reputation in cases where proof was inconclusive, nor does it seem likely that compliance with the other provisions of the Holifield Bill would have prevented such injury.

No fact-finding agency could be expected to be infallible, but the hearings indicate further that procedural rules cannot insure a fair hearing in this area. Defects in the Committee's procedure were manifest notwithstanding the observance of so many of the suggested rules. Friendly witnesses were not properly cross-examined $^{3 x}$ while hostile witnesses were often browbeaten. ${ }^{32}$ The failure

functioning as a court, don't have the power, unfortunately, that a court does have, and so we have not made it a policy to cross-examine witnesses or to permit counsel to do so. Had we the full authority of a court, certainly it would be easier to get down into the disputed evidence in this particular case. Since we do not have, we cannot adapt ourselves to part of the rules of the court without having the authority that goes with being a court. ..."

${ }^{28}$ The questions submitted by Alger Hiss were asked of Whittaker Chambers. Ibid., at xI65-67, Ir96-x 200 .

${ }^{29} \mathrm{Ibid}$., at I096, Irr6. It may be noted that the witness involved, Alger Hiss, raised some question as to the Committee's cooperation.

${ }^{30} \mathrm{~A}$ clear statement of the Committee's position was made by Representative Nixon. "The procedure of this committee is that the witness has the right to have counsel. The witness, when he is asked a question may at any time consult with counsel, and counsel may advise him as to whether or not there are any constitutional objections to the question which is being phrased. The witness may state his objection in refusing to answer the question or in qualifying his answer in any way; but the procedure of the committee does not allow for counsel to interpose objections to questions during the course of a hearing, or to present answers to questions or to make arguments. The witness has a perfect right to consult counsel on every question if he wishes, but the witness must take the initiative in that respect." Ibid., at ror6. In this particular instance the witness' attorney was eventually allowed to state the objection. However, Committee members were often quite hostile to the idea, as shown by Representative Rankin's remark, "I want to congratulate the witness that ... he didn't bring a lawyer here to tell him what to say." Tbid., at 659. Cf. Attorney Braverman's experiences, ibid., at 1216, 1309, 1343-44.

${ }^{3 x}$ The cross-examination of Whittaker Chambers presents a notable exception to this tendency. See particularly, ibid., at 66I-72. Questioning directed only at matters of opinion was too of ten evidenced. An example is found in the questions which Representative Rankin asked Miss Bentley about Communism. Ibid., at 543-44. These culminated in the following: "In other words, it is nothing but a system of abject slavery, dominated by a racial minority, as members of the Politburo; is that correct?" As to the type of evidence admitted virtually unquestioned, Representative Rankin's remarks concerning the case of Laughlin Currie are instructive. "[W]e have put in the whole day accepting from an ex-Communist . . . testimony relayed through two Communists as to what this man Currie in the White House is supposed to have said. Now, that looks to me as if we are going pretty far afield when we take that kind of testimony and charge this all up to Mr. Currie.... But here we put in a whole day ... smearing Currie by remote control through two Communists, either one of whom you admit would swear to a lie just as soon as he would swear to the truth if it suited his purposes, and relayed to you [Miss Bentley], who at that time was a member of the Communist Party." Ibid., at 557 .

${ }^{32}$ Ibid., at $1329-46$. 
to conclude the inquiry, to prove or reject charges made, allowed possibly unfounded suspicions of guilt to settle indefinitely on the reputations of all involved. ${ }^{33}$ And the willingness of the Committee to permit virtually anyone to use its facilities to denounce others as un-American ${ }^{34}$ unduly enhanced the possibility for defamation. The lesson is clear: many of the avenues by which committee bias may lead to unfairness cannot be closed by legislative rules. Too great a curtailment of the discretion indispensable to legislative inquiry would be necessary. Moreover, procedural rules are difficult to enforce. Unlike administrative agencies congressional committees do not make determinations of legal status which can be reviewed by an appellate tribunal, 35 and it is improbable that Congress would inflict penalties on its own members. Public opinion, therefore, remains as the principal safeguard.

\section{II}

A criminal prosecution for perjury ${ }^{36}$ most readily comes to mind as a judicial corrective; it has been relied upon by the Un-American Activities Committee as a sufficient guarantee that the truth will be established from conflicting testimony. ${ }^{37}$ Yet the penalties for this crime have proved a very ineffective detriment to lying under oath. ${ }^{38}$ Requirements for the proof of perjury are even more

33 This criticism must be qualified in light of the possibility that recently uncovered documentary evidence may substantiate the accusations made by Whittaker Chambers. Nevertheless, the record of the hearings indicates that no conclusive proofs were intended or expected by the Committee. See ibid., at II59, where Representative Mundt told Alger Hiss: "This Committee never had any illusions that we would be able to prove definitely whether or not you are a Communist because, in dealing with people charged with being Communists over a period of years, we have found that those who are guilty, refused to admit it and dodged the question, or deliberately lied. ... We know that we cannot get their membership cards, but that was a point we could not hope to establish by verifiable evidence, and it is now a point in dispute." But cf. House Committee on Un-American Activities, Io Things You Should Know about Communism in the U.S.A., at II (I948): "62. How can a Communist be identified? It is easy. Ask him to name ten things wrong with the United States. Then ask him to name two things wrong with Russia. His answers will show him up even to a child. Communists will denounce the President of the United States but they will never denounce Stalin."

34 See Representative Hébert's oration on credibility of witnesses. House Committee on Un-American Activities, op. cit. supra note 9, at 952. "We have to have people like Chambers or Miss Bentiey to come in and tell us. I am not giving Mr. Chambers any great credit for his previous life. I am trying to find out if he has reformed. Some of the greatest saints in history were pretty bad before they were saints. Are you going to take away their sain thood because of their previous lives? Are you not going to believe them after they have reformed? I don't care who gives the facts to me, whether a confessed liar, thief, or murderer, if it is facts."

35 For description of the elaborate system of review provided in the federal loyalty program, see Abbott, The Federal Loyalty Program, 42 Am. Pol. Sci. Rev. 486 (I948); but see Emerson and Helfeld, Loyalty among Government Employees, 58 Yale L.J. I (I948).

${ }^{36}$ I8 U.S.C.A. 8 I62x (I948).

37 House Committee on Un-American Activities, op. cit. supra note 9, at 95I, 953; House Committee on Un-American Activities, op. cit. supra note 2, at 14 . One witness, Alger Hiss, has been indicted for perjury. Chi. Daily News, p. I, col. 7 (Dec. 16, 1948).

${ }^{38}$ See McClintock, What Happens to Perjurers, 24 Minn. L. Rev. 727 (I940); Scott, Nothing but the Truth, 7 Mass. L. Soc. J. I2 (1936); Hibschman, You Do Solemnly Swear, 24 J. 
stringent than those necessary in the case of murder. It is not enough to present evidence establishing guilt beyond a reasonable doubt; the government must show that the statement was false "by the testimony of two independent witnesses or one witness and corroborating circumstances." 39 It is manifestly difficult to prove that testimony concerning political beliefs or alleged espionage activity is false, particularly when the testimony relates to events which occurred, if at all, many years ago; no statute of limitations applies to the activities of an investigating committee. An equally grave disadvantage of perjury prosecutions common to all criminal proceedings, is the necessity of relying on government officials to bring action. $4^{\circ}$ The possibility that the officials may be subjected to varied political pressures cannot be overlooked.

Imposing tort liability for defamation would be a possible supplement to the criminal sanctions of perjury. However, it is generally considered that an absolute privilege attaches to all defamatory matter published in the course of legislative proceedings, including committee hearings. ${ }^{4 \mathrm{I}}$ In the case of congressmen the immunity is expressly granted in the Constitution. ${ }^{27}$ However the extension of absolute privilege to press releases publicizing in advance the future proceedings of a congressional committee seems doubtful, 43 and there is authority that the immunity given legislators does not extend to the re-publication of statements made during the proceedings. 44

But the position of the witness before a committee is most vulnerable. The authority for the proposition that such a witness is absolutely protected from

Crim. L. 9or (1934); Purrington, The Frequency of Perjury, 8 Col. L. Rev. 67 (rgo8); Problem of Successful Perjury, 78 Sol. J. 423 (I934).

39 Weiler v. United States, 323 U.S. 606, 607 (1945). The rule has been strongly criticized in 7 Wigmore, Evidence $\$ \S 2040-43$ (3d ed., I940). As to differences in the law in other jurisdictions, see McClintock, What Happens to Perjurers, 24 Minn. L. Rev. 727, 745-46 (I940).

${ }^{4} \mathrm{In}$ the most exhaustive study of the problem, disinterest of the officials responsible for prosecuting was found more troublesome than over-technicality of the law. McClintock, What Happens to Perjurers, 24 Minn. L. Rev. 727, 750-53 (I940).

${ }_{41}^{4}$ See Prosser, Torts $827-29$ (I94I). Representative Nixon's concise restatement of the law is of in terest. "It is my opinion if a statement is made to an investigative officer not under subpoena, but voluntarily, voluntarily by the witness, that the statement would not be privileged. If the statement is made in this hearing, of course, it is privileged." House Committee on UnAmerican Activities, op. cit. supra note 9, at 989 .

$4^{2}$ U.S. Const. Art. I, $\$ 6:$ : . . . and for any Speech or Debate in either House, they [the Senators and Representatives] shall not be questioned in any other Place." See Cochrane v. Couzens, 42 F. $2 d 783$ (App. D.C., I930), cert. den. 282 U.S. 874 (r930).

${ }_{43}$ The Supreme Court in Kibourn v. Thompson, I03 U.S. I68, 204 (1880), although stating that the privilege was not limited to words spoken in debate, went no further than to say that "[ $[$ ] he reason for the rule is as forcible in its application to written reports presented in that body by its committees, to resolutions offered, which, though in writing, must be reproduced in speech, and to the act of voting, whether it is done vocally or by passing between the tellers. In short, to things generally done in a session of the House by one of its members in relation to the business before it."

${ }_{44}$ Rex v. Creevy, I M. \& S. 273 (18r3); Rex v. Abingdon, I Esp. 226, Peake 236 (I794); Rest., Torts $\S 590$, comment b (r938). 
libel and slander suits is surprisingly scant. 45 The courts have not considered this privilege as an extension of that accorded the legislator but have based it on the analogy of the immunity granted statements by a witness in a judicial proceeding..$^{6}$ Retrospectively, this development seems improper. Not only is remedial legislation desirable, but a persuasive argument can be directed against the rule in those courts where it has yet to be conclusively established.

The differences in the positions of judicial and legislative witnesses justify different rules of privilege. Enforcement of the rules of evidence, effective guarantees of thorough cross-examination, and the probability of a more impartial hearing in a judicial proceeding underline these differences. In addition there is a greater likelihood that all controverting evidence will be presented. Criminal prosecutions often must be initiated by a grand-jury indictment ${ }^{47}$ and, unlike many committee investigations, legal proceedings are resolved by a final verdict which ordinarily will be given much more publicity and credence than charges made in the course of the trial. Moreover, the widespread publicity afforded legislative investigations gives the congressional witness a far greater power to harm than his legal counterpart. $4^{8}$ The limited procedural reforms proposed would by no means obliterate these differences. Privileges in the law of defamation are based on the belief that the benefits to the public of free speech will outweigh the harm which may result to individuals. ${ }^{49}$ But congressional investigations have upset this balance. Because of the greater probability of harm it is submitted that public policy will best be served if a greater measure of protection is accorded to the individual by conferring only a qualified privilege on congressional witnesses.

The utility of thus extending the area of liability for defamation remains to be considered. The defendant witness would not necessarily be put to the truth of his accusations, for liability would still be conditioned on a showing by the plaintiff that there had been an abuse of a qualified privilege. This can be established by proving such matters as lack of belief by the defendant in the truth of the defamatory statements, the absence of reasonable grounds for so believing, or improper motives in making the accusations..$^{50}$ The burden of going

${ }^{45}$ Sheppard v. Bryant, I9I Mass. 59I, 78 N.E. 394 (I906); Goffin v. Donnelly, 6 Q.B.D. 307, 50 L.J.Q.B. 303 (I88I); Terry v. Fellows, 2 L La. Ann. 375 (I869); Kelly v. Daro, 47 Cal. App. 2d 4I8, I18 P. 2d 37 (I94I) (decided under the civil code of that state).

${ }^{6}$ See cases cited note 45 supra; Veeder, Absolute Immunity in Defamation: Legislative and Executive Proceedings, Io Col. L. Rev. I3I, I37 (I9ro).

47 Proceedings before grand juries are of course secret. See Am. Law Inst., Code of Criminal Procedure \& I43 (I943).

${ }^{48}$ Some judicial proceedings have undoubtedly been more widely publicized than some legislative investigations; it is a differential between averages which is important.

${ }^{49}$ See Rest., Torts c. 25, tit. b, introductory note (I938); Harper, Torts \$ 247 (I933); Veeder, Absolute Immunity in Defamation: Legislative and Executive Proceedings, to Col. L. Rev. I3I (I9IO).

so Rest., Torts $\$ \S 600,601,603$ (1938); Prosser, Torts 849-5I (I94I). 
forward with the evidence is not so heavy as to nullify the remedy. While it is true that the fallibility of juries and the time lag inherent in any action for damages render the remedy imperfect, ${ }^{\text {sI }}$ the threat of liability would at least be a partial deterrent to the conscious liar..$^{52}$

The cost of imposing procedural and judicial restrictions on congressional investigations, namely the loss of information otherwise available to the public, does not seem prohibitive. The fear is rather that the reforms will not be adequate to protect against unwarranted damage to reputation. Unfairness results not alone from activities within the committee room, but also from a public opinion which is swift to condemn where the charge is one of subversive activity. But since committee actions have a significant share in the molding of public opinion, the suggested reforms may well serve to alter the popular propensity to exaggerate the charges and to pronounce judgment without evidence, and remind us to be patient in judging those who are suspect and whom we do not like.

\section{THE STATUS OF HOTELS UNDER THE FEDERAL HOUSING AND RENT ACT*}

The Federal Housing and Rent Act of $1947^{2}$ was enacted by Congress in order

${ }^{5 x}$ It might also be thought that a possibility of injustice is inherent in a plan to abrogate absolute privilege as a result of the power of the legislative committee to compel testimony. It is possible that a witness under subpoena might be forced against his will to make defamatory statements that he believed true, while he would be unable to prove either the truth of the statement or non-abuse of his privilege. Such a remote possibility seems best prevented by a legislative rule granting a witness at a public hearing the privilege of refusing to make possibly defamatory statements. A hearing might result in which the names of persons accused of wrongdoing would be withheld; it would find its prototype in Miss Bentley's testimony before the Ferguson Committee. Hearings before the Investigations Subcommittee of the Senate Committee on Expenditures in the Executive Departments, on Export Policy and Loyalty, 8oth Cong. 2 d Sess. (I948). This privilege from testifying should not extend to secret or executive sessions, though the committee should not be permitted to publish statements made during such proceedings without the permission of the witness. A further advantage in enacting a rule permitting refusal to utter defamatory remarks is to be found in the aid it would give the courts in rejecting a rule of absolute privilege that was prompted in large part by the fact that witnesses in legislative investigations could be compelled to testify. Thus, the rule of Wright $v$. Lathrop, I49 Mass. 385,2 I.E. 963 (I889), allowing only a qualified privilege to the witness who volunteered unsolicited information might be found controlling. To be weighed against these advantages is the slight possibility that harmful defamatory silence might result from refusing to answer questions on this ground.

${ }^{52}$ It should be noted that Whittaker Chambers repeated charges made during the hearings in a radio broadcast for the purpose of giving Alger Hiss an opportunity to sue. N.Y. Times, $\S \mathbf{r}$ p. I, col. 2 (Sept. 28 , I948).

* This note deals with the 1947 and 1948 Acts. Recent legislation extending controls leaves unresolved many of the problems raised by the earlier legislation, and is discussed in an addendum, infra p. 566.

× 6I Stat. 193 (1947), 50 U.S.C.A. $\$ \S 1891-96,1898-1903$ (Supp., r947). The Act was extended for thirty-one days by Public Law 422, 8oth Cong. 2d Sess., 5० U.S.C.A. App. $\$ \S \mathrm{I} 884(\mathrm{a}), \mathrm{I} 894(\mathrm{a})$, ( $\mathrm{f}$, and subsequently amended by the Housing and Rent Act of $\mathrm{I} 948$, 62 Stat. 93 (I948), 50 U.S.C.A. $\$ 512$ (Supp., 1948). For an analysis of the entire Act see Willis, The Federal Housing and Rent Act of 1947,47 Col. L. Rev. III8 (I947). The I948 Act expired March 3I, x949. 